\title{
Econometric Modelling of Risk Adverse Behaviours of Entrepreneurs in the Provision of House Fittings in China
}

Rita Yi Man Li, (Hong Kong Shue Yan University, Hong Kong)

\begin{abstract}
Entrepreneurs have always born the risk of running their business. They reap a profit in return for their risk taking and work. Housing developers are no different. In many countries, such as Australia, the United Kingdom and the United States, they interpret the tastes of the buyers and provide the dwellings they develop with basic fittings such as floor and wall coverings, bathroom fittings and kitchen cupboards. In mainland China, however, in most of the developments, units or houses are sold without floor or wall coverings, kitchen or bathroom fittings. What is the motive behind this choice? This paper analyses the factors affecting housing developers' decisions to provide fittings based on 1701 housing developments in Hangzhou, Chongqing and Hangzhou using a Probit model. The results show that developers build a higher proportion of bare units in mainland China when: 1) there is shortage of housing; 2) land costs are high so that the comparative costs of providing fittings become relatively low.
\end{abstract}

Keywords: Imperfect information, Risk, Entrepreneur, Fittings, Probit model, Housing.

\section{Introduction}

In many places, such as Australia, the United Kingdom and the United States, housing developers provide floor and wall coverings, window frames, cupboards, and electrical fittings as standard equipment. In some cases, developers also provide heated floors and wine storage. There is, however, a completely different norm in mainland China. For instance, the majority of developers in Beijing and Nanjing sell bare dwellings to home buyers. There are no floor coverings, kitchen cupboards or basic bathroom fittings (Li, 2009). Table 1 shows the percentage of bare flats in Nanjing. Among all the residential developments available for sale in 2004 - 2007 in Nanjing, 90\% were bare units. Table 2 displays a similar phenomenon. It shows the percentage of bare flats in Beijing from 1997 2008. Of all the first hand residential units sold in Beijing districts, more than $70 \%$ were sold as bare units. Similarly, bare units can also be found in Shanghai and Hangzhou. This paper aims at finding out the major drivers behind these housing entrepreneurs to build bare residential units in these cities.

\section{Hypotheses}

Purchasing bare units without any fittings in mainland China implies that buyers need to spend time in identifying relevant parties to decorate their housing units before they move in. Why do busy people, often trapped in crammed schedules accept such a time consuming building activity? There has been very limited study of this phenomenon. This paper aims to remedy this and test potential reasons behind this by testing theories of brand name, risk adverse behaviours and information costs etc. Specifically, the author proposes four hypotheses on the emergence of bare flats:

1. Developers tend to build housing units with fittings in high land price areas.

2. The larger the proportion of low income residents the higher the proportion of bare flats.

3. Developers with well renowned reputations (brand names) build more furnished flats.

4. The greater the shortage of residential units, the higher the proportion of bare flats. 


\begin{tabular}{|c|c|c|}
\hline District & $\begin{array}{l}\text { Total residential developments available } \\
\text { for occupation in } 2004-2007^{1}\end{array}$ & Percentage of bare flats \\
\hline Bai Xia & 32 & 92 \\
\hline Da Han & 4 & 50 \\
\hline Gao Chun & 3 & 100 \\
\hline Gu Lou & 65 & 94 \\
\hline Jian & 71 & 93 \\
\hline Jiang Zhu & 133 & 98 \\
\hline Li Shui & 11 & 91 \\
\hline Lu He & 12 & 92 \\
\hline Pu Kou & 60 & 97 \\
\hline Qi Xia & 50 & 100 \\
\hline Qian Huai & 42 & 100 \\
\hline Xia Guan & 24 & 92 \\
\hline Xuan Wu & 35 & 92 \\
\hline
\end{tabular}

Table 1 Percentage of bare residential units in Nanjing (Li, 2010)

\begin{tabular}{|c|c|c|c|}
\hline District & $\begin{array}{l}\text { Residential projects } \\
\text { which build bare flats }\end{array}$ & Total & $\begin{array}{l}\text { Percentage of bare } \\
\text { flats }\end{array}$ \\
\hline Chao Yong & 618 & 853 & 72 \\
\hline Chong Ping & 160 & 182 & 88 \\
\hline Chong Wen & 62 & 74 & 84 \\
\hline Da Xing & 140 & 165 & 85 \\
\hline Dong Cheng & 59 & 79 & 75 \\
\hline Fang Shan & 83 & 90 & 92 \\
\hline Feng Toi & 260 & 305 & 85 \\
\hline Hai Dian & 379 & 470 & 81 \\
\hline Huai Rou & 37 & 44 & 84 \\
\hline Mi Yun & 43 & 52 & 83 \\
\hline Shi Jing Shan & 48 & 54 & 89 \\
\hline Shun Yi & 102 & 126 & 81 \\
\hline Tong Zhou & 194 & 219 & 89 \\
\hline Xi Cheng & 62 & 82 & 76 \\
\hline Xuan Wu & 88 & 114 & 77 \\
\hline Yan Qing & 17 & 24 & 71 \\
\hline Others & 92 & 110 & 84 \\
\hline
\end{tabular}

Table 2 Percentage of bare flats in Beijing from 1997 - 2008 (Li, 2009)

\footnotetext{
${ }^{1}$ Each of the residential development refers to one residential project. Some of the projects consist of up to, or more than 1000 units. The districts refer to small areas inside the city. This applies also to Table 2.
}

Li, R Y M (2012) 'Econometric modelling of risk adverse behaviours of entrepreneurs in the provision of house fittings in China', Australasian Journal of Construction Economics and Building, 12 (1) 72-82 
The first proposition: Developers tend to build housing units with fittings in areas with high land prices.

While fittings in high land price areas only make up a small proportion in construction costs, fittings in low land price areas constitute a relatively large share. The costs of providing fittings which do not suit the taste of customers are relatively lower in areas with high land prices compared to the costs of providing wrong fittings in areas with low land prices as home purchasers might choose not to buy the flats when developers provide unsuitable fittings. As developers are risk adverse, it is natural that they provide fewer fittings in those areas to avoid the relatively high risks:

$$
P(f) / L_{H}<P(f) / L_{L}
$$

where $P(f)$ refers to the price of the fittings, $L_{H}$ refers to high land price area and $L_{L}$ refers to low land price area.

The second proposition: The larger the proportion of low income residents, the higher the proportion of bare flats.

Developers in affluent countries such as United Kingdom, Singapore, United States offer more fittings as compared to those in developing countries, such as China, Ghana, Indonesia etc. Buying favourite fittings implies that the buyers are investing the time and money in the act of searching information. A man who earns $\$ 4$ per hour has a low discretionary income but may be happy to search by himself rather than pay the contractor to do all on behalf of him, while a man who earns $\$ 400$ finds it not worthwhile to do so. Searching costs him $\$ 400$ per hour which is more than the cost of letting the contractor do it. In view of this, high income areas theoretically should have a smaller portion of bare flats. Developers tend to build more well-furnished flats with fittings to suit the needs of customers.

The third proposition: Developers with well developed reputations build more wellfurnished flats and vice versa.

Bare dwellings may avoid losses but do not help the developers to maximize gains from value added. Hence, well regarded developers may tend to build more housing units with good fittings to enhance their reputation for quality. For others, it may be better to provide no fittings as the provision of poor fittings may set back reputations which have taken years to build up.

The fourth proposition: The supply is so limited that the huge demand lowers developers' motivations to provide well-equipped units.

Previous literature shows that shortages may lead to use of unqualified staff and poor materials. Compared to many overseas countries, China experiences a shortage of housing by private developers. With substantial excess demand, developers do not need any gimmicks to compete for potential buyers. Provisions of kitchen and bathroom fittings are unnecessary.

\section{Literature Review}

\section{Assumptions, Functions and Factors affecting the Supply of Entrepreneurs}

Another important role played by entrepreneurs is risk-taking. Entrepreneurs are risk-takers (Blanchflower and Oswald, 1998) who accept the firms' risks (Carland et al., 1984) when running a business. 


\section{Information, Imperfect Information and Asymmetric Information}

One major problem that the entrepreneurs face is imperfect information. Imperfect information affects market power and prices and leads to a dis-equilibrium where firms can charge monopoly prices (Granlund and Rudholm, 2011). Hence asymmetric information is a market failure which undermines the efficiency of product transactions. It is not unusual that consumers are uninformed about risks which affect their ability to choose terms which reflect their preferences correctly. Firms often exploit this ignorance by degrading contract quality intentionally and will then have little incentive to offer better deals as these will not increase sales (Bechern, 2008).

\section{Risk-averse Human Behaviour}

Because of imperfect information, individuals and entrepreneurs make their decisions under risk. Risk has been identified as the potential for threat, damage, injury, or other loss (Zou et al., 2007, Jin and Doloi, 2008). It may also be conceptualized as variance in outcome in any project (Das and Teng, 2001, Fellner and Maciejovsky, 2007). Risk can be managed by catastrophe planning, easing, insurance, control, identification, quantification and shifting it to other agents (Zou et al., 2007, Jin and Doloi, 2008).

People's attitude to risk affect their behaviour and is important in decision making (Richard, 1975, Xiao and Yang, 2008). People's attitude towards risks is not consistent. Some people are more risk adverse than the others.

Buyers cannot obtain information on housing quality from the previous owners when they buy new housing. Many of them only know they have bought a poor housing when they open the doors of their units (Gwin and Ong, 2000). Therefore, home buyers often rely on developers' reputation and previous residential project to make decisions so as to minimise their risk in home purchases.

\section{Loss-averse Human Behaviour}

Apart from risk aversion, many entrepreneurs are loss-averse which refers to a situation when decision-makers are more sensitive to losses than to gains. This phenomenon represents a discontinuity in their utility function (Berkelaar et al., 2004), graphically expressed as an abrupt change in the slope of the utility function at the reference point (Wang et al., 2009) which distinguishes gains from losses It also signifies that the utility function is steeper for losses than for gains, i.e. the disutility that one experiences in losing money is greater than the utility associated with gaining the same amount. Loss aversion has become an important tool to explain all sorts of phenomena which are not explained by traditional theory, such as the endowment effect (Tovar, 2009).

\section{Branded Product}

A brand name is a firm's most important asset when it comes to evaluating companies against each another (Laforet, 2011). Entrepreneurs spent a lot of effort on boosting the name of their companies. Branded products have valuable merits to consumers as well as sellers (Table 3 ) as they convey quality information to consumer. As early as 1960s, the American Marketing Association defined "brand" as:

\footnotetext{
"a name, term, sign symbol or design, or a combination of these, intended to identify the goods or services of one seller or group of sellers and to differentiate them from those of competitors" (Zilg, 2011, p.284).
}

With asymmetric information in China's housing industry, buyers use brand names to assess product quality. Reputation is an effective signal which provides quality information because it is firm-specific - gradually built up from the quality of the projects built by a developer in the past. In case where developers have a history of working in a community, home buyers can obtain information on quality of the units by observing previous projects.

Li, R Y M (2012) 'Econometric modelling of risk adverse behaviours of entrepreneurs in the provision of house fittings in China', Australasian Journal of Construction Economics and Building, 12 (1) 72-82 


\begin{tabular}{|c|c|}
\hline Merits of brand name & Examples \\
\hline $\begin{array}{l}\text { Allows firms to escape from the } \\
\text { confines of generic prices }\end{array}$ & $\begin{array}{l}\text { Jensen and Drozdenko (2008); LeBel and Cooke (2008); } \\
\text { Rotfeld (2004); Vukasovič (2009); Souiden and Pons (2009) }\end{array}$ \\
\hline Easier adoption of a new product & Rotfeld (2004), Vukasovič (2009) \\
\hline Price premium & $\begin{array}{l}\text { Corkindale and Belder (1985); ; Olson (2008); Chen } \\
\text { (2007) ; Li et al. (2009) disagree) }\end{array}$ \\
\hline $\begin{array}{l}\text { Enhance perceptions of product or } \\
\text { service quality }\end{array}$ & $\begin{array}{l}\text { Corkindale and Belder (1985); Horppu et al. (2008); } \\
\text { Shannon and Mandhachitara (2008); Vukasovič (2009); }\end{array}$ \\
\hline Facilitate promotional effectiveness & Corkindale and Belder (1985) \\
\hline $\begin{array}{l}\text { The "personality" of brand product } \\
\text { add value to the consumer }\end{array}$ & Charters (2011) \\
\hline Increase market share & Vukasovič (2009) \\
\hline Decrease risk & Vukasovič (2009); Matzler et al. (2008) \\
\hline Barrier to entry for competitors & Omar et al. (2009) \\
\hline Provides information to the consumer & $\begin{array}{l}\text { Baltas and Saridakis (2009); Pechtl (2008); Pitta and } \\
\text { Franzak (2008); Souiden and Pons (2009) }\end{array}$ \\
\hline Product differentiation & Zilg (2011) \\
\hline $\begin{array}{l}\text { To attract a group of loyal customers } \\
\text { Not likely for housing }\end{array}$ & Burnett and Bruce (2007); Horppu et al. (2008) \\
\hline
\end{tabular}

Table 3 Merits of brand name

\section{Shortage and Sellers' Goods Quality}

Market forces not only affect prices, they also determine suppliers' incentives to provide 'extra' value which aims at being perceived as quality improvement. In case of shortage, suppliers do not need to compete with other sellers. As a result, they may minimize production costs by providing only limited accessories to their buyers (Hawthorne and Birrell, 2002, Ingersoll and Smith, 2003).

Housing investment in the planned economy was limited before 1976. The government preferred to spend money on investments other than housing (Wang and Murie, 1996). Private housing investment was allowed after the death of Mao and rapid growth in population and subsequent alterations in national urban policy have brought about a rapid urbanization in China. Registered urban population has been increasing at a rate of $4 \%$ annually since 1980 (Wu, 1999). Residential unit supply never met demand. Housing shortages problems had became serious by the end of the Cultural Revolution in 1976 when there was only $3 \mathrm{~m}^{2}$ of floor space per person on average. Despite the large quantity of housing that had been built since 1978, 4 million urban households still live with $4 \mathrm{~m}^{2}$ per family member in 1994 and 400000 had an average of $2.5 \mathrm{~m} \mathrm{~m}^{2}$ living space per person (Wang and Murie, 1996).

In view of the above, does it mean that the popularity of bare units in China is the results of a shortage of housing, risk adverse behavior by developers or something else?

\section{Research Method - Probit Model}

To find out the reasons behind the sale of bare units in China, the Probit model will be used. Covariates are measured from errors in regression model estimates. In binary dependent variables, the error term can also be dichotomous in nature, hence normal distribution assumption of error term in ordinary least square is not essential. Therefore, OLS regression which is suitable for continuous dependent variables may not be the best choice in case of dichotomous dependent variables to estimate an equation (Gujarati, 2006). 
In a binary response model, interest lies primary in the response probability

$$
\begin{gathered}
Y^{*}=X t \\
P(y=1 \mid x)=P\left(y 1 \mid x_{1}, x_{2}, \ldots, x_{k}\right)
\end{gathered}
$$

Consider an equation with binary response $(0,1)$ :

$$
P(y=1 \mid x)=Y\left(\partial_{0}+\partial_{1} x_{1}+\partial_{2} x_{2}+\ldots+\partial_{k} x_{k}\right)=Y\left(\partial_{0}+x \partial\right)
$$

Where $\mathrm{x}$ denotes a complete set of explanatory variables, $\mathrm{Y}$ is a function which takes on values between 0 and 1 , that is $0<Y(z)<1$ where t represents all the real numbers $x \delta=\partial_{1}$ $b_{1}+\partial_{2} b_{2}+\ldots+\partial_{k} b_{k}$ (Wooldridge, 2003).

\section{Data Analysis}

Data of provincial GDP per capita, construction costs for each year, annual supply of newly built residential units and change in number of household, background information of the

\begin{tabular}{|c|c|c|c|c|c|c|c|}
\hline Year & $\begin{array}{l}\text { Real GDP } \\
\text { per capita }\end{array}$ & $\begin{array}{l}\text { Construc- } \\
\text { tion costs } \\
\left(\mathrm{m}^{2}\right)\end{array}$ & $\begin{array}{c}\text { Number of } \\
\text { develop- } \\
\text { ment }\end{array}$ & $\begin{array}{l}\text { Average } \\
\text { Estimated } \\
\text { Land Cost } \\
\left(\text { per } \mathrm{m}^{2}\right)\end{array}$ & $\begin{array}{c}\text { Change in } \\
\text { No of } \\
\text { Households } \\
\text { (ten } \\
\text { thousand) }\end{array}$ & $\begin{array}{c}\text { Area of } \\
\text { newly built } \\
\text { dwelling } \\
\text { (ten } \\
\text { thousand } \\
\text { m }^{2} \text { ) }\end{array}$ & $\begin{array}{l}\text { Percentage } \\
\text { of bare } \\
\text { deve- } \\
\text { lopment (\%) }\end{array}$ \\
\hline \multicolumn{8}{|c|}{ Hangzhou (Hangzhou Statistics Bureau, 2008, Hangzhou Soufun, 2009) } \\
\hline 2003 & 32667 & 2275 & 26 & 9350 & 2.85 & 516 & 82 \\
\hline 2004 & 38593 & 2023 & 61 & 11435 & 3.40 & 528 & 83 \\
\hline 2005 & 44555 & 2459 & 62 & 11535 & 2.90 & 662 & 83 \\
\hline 2006 & 51650 & 2340 & 51 & 10484 & 2.49 & 580 & 81 \\
\hline 2007 & 52590 & 2953 & 59 & 6616 & 2.08 & 675 & 81 \\
\hline \multicolumn{8}{|c|}{ Chongqing (Chongqing, 2008, Hangzhou Soufun, 2009) } \\
\hline 2003 & 7261 & 827 & 47 & 3242 & 15.32 & 1232 & 85 \\
\hline 2004 & 7633 & 929 & 80 & 3281 & 11.58 & 1228 & 90 \\
\hline 2005 & 7745 & 1074 & 106 & 3694 & 21.82 & 1714 & 93 \\
\hline 2006 & 7689 & 1319 & 146 & 2800 & 20.25 & 1700 & 93 \\
\hline 2007 & 7854 & 1452 & 151 & 3023 & 26.31 & 1769 & 93 \\
\hline \multicolumn{8}{|c|}{ Shanghai (Shanghai Statistics Bureau, 2008, Shanghai Soufun, 2009) } \\
\hline 2003 & 39128 & 2987 & 149 & 6294 & 4.29 & 2281 & 88 \\
\hline 2004 & 46338 & 2958 & 180 & 8107 & 4.52 & 3270 & 83 \\
\hline 2005 & 51529 & 2960 & 304 & 7204 & 6.11 & 2819 & 84 \\
\hline 2006 & 57695 & 2963 & 151 & 8491 & 2.85 & 2747 & 80 \\
\hline 2007 & 66367 & 3014 & 128 & 9319 & 3.75 & 2844 & 80 \\
\hline
\end{tabular}
residential developments such as developers which built the dwellings were collected to test the four hypothesis listed at the beginning of the paper.

Table 4 Economic and housing data

2003 - 2007 GDP per capita data of the three places - deflated by GDP deflator - were obtained from Statistics Bureau in each place (Shanghai Statistics Bureau, 2008, Chongqing, 
2008, Hangzhou Statistics Bureau, 2008). Land price was a proxy obtained by subtracting the average selling price of residential units (Shanghai Soufun, 2009, Wooldridge, 2003, Soufun, 2009) by construction costs available from the respective Statistical Year Books of (Shanghai Statistics Bureau, 2008, Chongqing, 2008, Hangzhou Statistics Bureau, 2008).

The table below summarizes the abovementioned information in Hangzhou. In this five year' period, about $80 \%$ of the dwellings were bare units. The number of developments ready for sale has been fairly constant at about 50 - 60 per year. The real GDP per capita ${ }^{2}$ rose from 32667 to 52590 in 2003 and 2007 respectively. Construction costs have increased since 2004. Estimated land costs have risen from 9350 in 2003 to 10484 in 2006 but dropped to 6616 in 2007. In Hangzhou, during this five year period GDP per capita has increased from 32667 in 2003 to 52590 in 2007 . Construction costs per $\mathrm{m}^{2}$ and number of residential developments rose from 827 to 1452 and 47 to 151 during the five years' observation period respectively. In Shanghai, the percentage of bare units dropped from 88 to 80 between 2003 and 2007. Number of housing developments rose from 149 to 304 in 2003 and 2005 but decreased afterwards and reached a trough of 128 in 2007. Construction costs oscillated around 2900 in this 5 year period. Annual change in number of household rose from 42900 to 61100 between 2003 and 2005, dropped to 28500 in 2006 and rose to 37500 in 2007. Area of newly built dwellings climbed from $22,810,000 \mathrm{~m}^{2}$ in 2003 and reached a maximum at $32,700,000 \mathrm{~m}^{2}$ in 2004 (Table 4).

\section{Research Results and Analysis}

To test the hypothesis, five variables LDMV, BUILDONCE, BUILDONCE*LOG(CCMV), A_CHANGEHSE, and GDP were included (Table 5). Table 6 Results of Probit regression

shows the results of the Probit regression.

\begin{tabular}{|l|l|}
\hline \multicolumn{1}{|c|}{ Variables } & \multicolumn{1}{c|}{ Explanation } \\
\hline LDMV & $\begin{array}{l}\text { Land price divided by open market value of the dwellings that is, } \\
\text { selling price of the units. }\end{array}$ \\
\hline BUILDONCE & $\begin{array}{l}\text { It represents developers which built once only during the study } \\
\text { period. As branded developers are characterized by repeated sales, } \\
\text { dummy "1" is assigned if the housing development was built by a } \\
\text { developer which had built once only and "0" if they had engaged in } \\
\text { repeated sales activities from 2004 - 2007. }\end{array}$ \\
\hline A_CHANGEHSE & $\begin{array}{l}\text { To test the impact of housing shortage on provision of fittings, } \\
\text { dwelling space was divided by the change in number of household } \\
\text { (Powell and Ansic, 1997) and it is represented by A_CHANGEHSE. }\end{array}$ \\
\hline BUILDONCE*LOG(CCMV) & CCMV denotes the proportion of construction cost in dwelling value. \\
\hline
\end{tabular}

Table 5 Variables in Probit model

The Probit regression models confirm the hypothesis that there is a significant negative relationship between bare units and land costs: there is a higher probability that developers build bare units when the land costs are low. Costs of fittings provisions become relatively high in low land costs areas as compared to the whole construction costs. On top of that, buyers may choose not to purchase units if the fittings do not suit their tastes. China is a newly emerging real estate market as there were no private companies prior to 1978 due to the planned economy. Hence many housing entrepreneurs are newcomers to the industry and lack information for predicting buyers' tastes in house fittings. In sharp contrast, the well established markets in places, such as Hong Kong, Europe, and Australia have enabled

\footnotetext{
${ }^{2}$ All costs and prices are expressed in RMB unless otherwise specified. Currently 1 USD equals 6.23 RMB
}

Li, R Y M (2012) 'Econometric modelling of risk adverse behaviours of entrepreneurs in the provision of house fittings in China', Australasian Journal of Construction Economics and Building, 12 (1) 72-82 
local housing entrepreneurs in these locations to learn about the preferences of buyers. Housing developers are risk averse. They all aim to maximise their profits without too much risk. To reduce their risk, these entrepreneurs choose not to provide any fittings. Furthermore, traditional entrepreneurs relay on many sources of external financing: debt, venture capital, private equity and public stock offerings. Investors who commit funds to business start-ups expect to receive back their investment along with a handsome return. Entrepreneurs must ask themselves if their goals are congruent with those of possible investors (Williams et al., 2006). If housing entrepreneurs make an incorrect decision, such as putting undesirable fittings into their units, investors will be affected and develop negative opinions about these entrepreneurs. Potential joint ventures may also become futile if the housing entrepreneurs have a history of incorrect decisions. Under the postulate of being risk averse, developers prefer to provide nothing inside the units.

The Probit Regression results also confirm our hypothesis that there is a significant positive relationship between repeated sales activities and furnished units. Nonetheless, the results of the interaction term BUILDONCE*LOG (CCMV) shows that not all "new" developers are equally keen to construct bare housing. The higher the construction cost as a proportion of property price, the higher would be the risk that the monetary return cannot cover the cost.

The literature indicated that shortages can lead to lower consumer requirement, and this is supported in this Probit model - there is an increase in likelihood of bare units construction in times of housing shortage. However, the insignificant relationship between GDP per capita and bare units, implies that people with higher information costs may not necessarily prefer well-furnished units.

\begin{tabular}{|c|c|c|c|c|}
\hline \multicolumn{5}{|l|}{ Dependent Variable: BARE } \\
\hline \multicolumn{5}{|c|}{ Method: ML - Binary Probit (Quadratic hill climbing) } \\
\hline \multicolumn{5}{|c|}{ Included observations: 1704} \\
\hline \multicolumn{5}{|c|}{ Convergence achieved after 5 iterations } \\
\hline \multicolumn{5}{|c|}{ Covariance matrix computed using second derivatives } \\
\hline Variable & Coefficient & Std. Error & z-Statistic & Prob. \\
\hline C & 2.320284 & 0.698542 & 3.321609 & 0.0009 \\
\hline LOG(LDMV) & -0.645794 & 0.233331 & -2.767715 & 0.0056 \\
\hline BUILDONCE*LOG(CCMV) & 0.614759 & 0.129308 & 4.754215 & 0.0000 \\
\hline BUILDONCE & 0.919487 & 0.193384 & 4.754730 & 0.0000 \\
\hline LOG(A_CHANGEHSE) & -0.259066 & 0.100172 & -2.586210 & 0.0097 \\
\hline LOG(GDP) & -0.007551 & 0.113477 & -0.066540 & 0.9469 \\
\hline McFadden R-squared & 0.106837 & \multicolumn{2}{|c|}{ Mean dependent var } & 0.861502 \\
\hline S.D. dependent var & 0.345523 & \multicolumn{2}{|c|}{ S.E. of regression } & 0.325198 \\
\hline Akaike info criterion & 0.725551 & \multicolumn{2}{|c|}{ Sum squared resid } & 179.5704 \\
\hline Schwarz criterion & 0.744708 & \multicolumn{2}{|c|}{ Log likelihood } & -612.1692 \\
\hline Hannan-Quinn criter. & 0.732642 & \multicolumn{2}{|c|}{ Restr. log likelihood } & -685.3946 \\
\hline LR statistic & 146.4507 & \multicolumn{2}{|c|}{ Avg. log likelihood } & -0.359254 \\
\hline \multicolumn{5}{|l|}{ Prob(LR statistic) } \\
\hline Obs with $\mathrm{Dep}=0$ & 236 & Total ol & & 1704 \\
\hline Obs with Dep=1 & 1468 & & & \\
\hline
\end{tabular}

Table 6 Results of Probit regression

Li, R Y M (2012) 'Econometric modelling of risk adverse behaviours of entrepreneurs in the provision of house fittings in China', Australasian Journal of Construction Economics and Building, 12 (1) 72-82 


\section{Summary}

An entrepreneur is the major driving force behind production of goods as he/she combines the resources of land, capital and labour. All entrepreneurs share one characteristic: they bear risk and earn profit or suffer losses in return. It is assumed here that housing entrepreneurs are risk averse. They attempt to find ways to reduce their risk. Housing entrepreneurs in mainland China who provide bare units provide a vivid example of risk aversion. As there is no guarantee of making a profit and there is imperfect information in our business world, the entrepreneur must assess the risk and, like other entrepreneurs, he/she cannot accept a job that has too high a risk of loss (Brue et al., 2009).

Running a development business is risky; it requires substantial capital investment in land, professional training and recruitment. Nevertheless, this huge expenditure does not guarantee a great return, and it is possible to suffer a substantial loss if the entrepreneur makes a wrong decision. Provision of home fittings is one of the risks that the housing entrepreneur faces. Some home buyers may dislike the fittings and thus decide not to purchase the home. In some places such as Hong Kong, land supply is scarce, but demand is huge (7 million people live in a small city with a hilly landscape). Land price occupies a relatively large proportion of the costs of dwelling production. Provision of fittings amounts to only a small proportion of the total costs of construction. Entrepreneurs thus focus on land purchases more than provision of fittings. The risk of installing fittings is not very high. Furthermore, many developers have run their business for many years and have accumulated sufficient knowledge on buyers' taste. Provision of fittings to customers is common. Yet, in mainland China, especially in areas of low land costs, costs of fittings have become relatively high. The risk of supplying fittings that prospective owners dislike is higher and this leads to the phenomenon of the bare flats' sale in China's real estate market.

A housing shortage reduces the pressure on developers to provide more than the most basic dwellings hence increasing the probability that developments will be sold without fittings. Changes in per capita income do not change this tendency in any significant way.

\section{Conclusion}

In conclusion, developers exhibit a higher tendency to build bare units when:

1. There is shortage of housing so that developers do not need to face intense competition and supply extra stuff, i.e. fittings in addition to the building structure itself;

2. Land costs are low; the costs of providing fittings become relatively high and developers tend not to take the risk of speculating in consumers' taste of fittings;

3. There were no repeated sales during the observation period, hence consumers have little guide to predict the quality of fittings.

4. And Finally, there is an insignificant relationship between proportion of bare units construction and income.

This paper has also demonstrated that Probit is a powerful tool for this type of analysis.

\section{References}

Baltas, G. and Saridakis, C. (2009) 'Brand-name effects, segment differences, and product characteristics: an integrated model of the car market', Journal of Product \& Brand Management, 18, 143-151

Bechern, S. I. (2008) 'Asymmetric information in consumer contracts: The Challenge that is yet to be met', American Business Law Journal, 45, 723-774

Berkelaar, A. B., Kouwenberg, R. and Post, T. (2004) 'Optimal portfolio choice under loss aversion', The Review of Economics and Statistics, 86, 973-987

Blanchflower, D. G. and Oswald, A. J. (1998) 'What makes an entrepreneur?', Journal of 


\section{Labor Economics, 16, 26-60}

Brue, S. L., Mcconnell, C., R. and Flynn, S. M. (2009) Essentials of Economics, New York, McGraw Hill

Burnett, J. and Bruce, H., R. (2007) 'New consumers need new brands', Journal of Product \& Brand Management, 16, 342-347

Carland, J. W., Hoy, F., Boulton, W. R. and Carland, J. A. C. (1984) 'Differentiating entrepreneurs from small business owners: A conceptualization', The Academy of Management Review, 9, 354-359

Chen, H. L. (2007) 'Gray marketing and its impacts on brand equity', Journal of Product and Brand Management, 16, 247-256

Chongqing, S. I. O. (2008) Chongqing Statistical Yearbook 2008 [Online] Available: http://www.cati.gov.cn/tinj/2008/yearbook/indexe.htm [Accessed 30 April 2010].

Das, T. K. and Teng, B. S. (2001) 'Trust, control, and risk in strategic alliances: An integrated framework', Organization Studies, 22, 251-283

Fellner, G. and Maciejovsky, B. (2007) 'Risk attitude and market behavior: Evidence from experimental asset markets', Journal of Economic Psychology, 28, 338-350

Granlund, D. and Rudholm, N. (2011) 'Consumer information and pharmaceutical prices: Theory and evidence', Oxford Bulletin of Economics and Statistics, 73, 230-254

Gujarati, D. N. (2006) Essentials of Econometrics, Boston, McGraw-Hill/Irwin

Gwin, C. R. and Ong, S. E. (2000) 'Homeowner warranties and building codes', Journal of Property Investment \& Finance, 18, 456-472

Hangzhou Soufun (2009) Hangzhou Soufun [Online] Available: http://hz.soufun.com [Accessed 1 May 2010]

Hangzhou Statistics Bureau (2008) Hangzhou Statistical Yearbook [Online] Available: www.hzstats.gov.cn/web/tinj/nj2008 [Accessed July 2009]

Hawthorne, L. and Birrell, B. (2002) 'Doctor shortages and their impact on the quality of medical care in Australia', People and Place, 10, 55-67

Horppu, M., Kuivalainen, O., Tarkiainen, A. and Ellonen, H. K. (2008) 'Online satisfaction, trust and loyalty, and the impact of the offline parent brand', Journal of Product \& Brand Management, 17, 403-413

Ingersoll, R. M. and Smith, T. M. (2003) 'The wrong solution to teacher shortage', Education Leadership, 60, 30-33

Jensen, M. and Drozdenko, R. (2008) 'The changing price of brand loyalty under perceived time pressure', Journal of Product \& Brand Management, 17, 115-120

Jin, X. H. and Doloi, H. (2008) 'Interpreting risk allocation mechanism in public privatepartnership projects: an empirical study in transaction cost economics perspective', Construction Management and Economics, 26, 707-721

Laforet, S. (2011) 'Brand names on packaging and their impact on purchase preference', Journal of Consumer Behaviour, 10, 18-30

Li, H., Tang, F. F., Huang, L. and Song, F. (2009) 'A longitudinal study on Australian online DVD pricing', Journal of Product \& Brand Management, 18, 60-67

Li, R. Y. M. (2009) 'Legal regulations, people's perceptions on law and scope of services provided by firms: a study on dwelling developers in Beijing and Hong Kong', The Business Review, Cambridge, 12, 221-226

Li, R. Y. M. (2010) Factors Influencing Developers' Decision to Sell Housing Units With Fittings - Empirical Evidence from China, The University of Hong Kong, Unpublished Ph.D. 
Thesis

Matzler, K., Kräuter, S. G. and Bidmon, S. (2008) 'Risk aversion and brand loyalty: the mediating role of brand trust and brand affect', Journal of Product \& Brand Management, 17, 154-162

Olson, E. L. (2008) 'The implications of platform sharing on brand value', Journal of Product \& Brand Management, 17, 244-253

Omar, M., Williams, R. L. and Lingelbach, D. (2009) 'Global brand market-entry strategy to manage corporate reputation', Journal of Product \& Brand Management, 18, 177-187

Pitta, D. A. and Franzak, F. J. (2008) 'Foundations for building share of heart in global brands', Journal of Product \& Brand Management, 17, 64-72

Powell, M. and Ansic, D. (1997) 'Gender differences in risk behaviour in financial decisionmaking: an experimental analysis', Journal of Economic Psychology, 18, 605-628

Richard, S. F. (1975) 'Multivariate risk aversion, utility independence and separable utility functions', Management Science, 22, 12-21

Shanghai Soufun (2009) Shanghai Soufun [Online] Available: http://sh.soufun.com/ [Accessed 1 July 2009]

Shanghai Statistics Bureau (2008) Shanghai Statistics Yearbook 2008 [Online] Available: http://www.stats-sh.gov.cn/2004shtj/tjnj/tinj2008.htm\# [Accessed 2 October 2009]

Shannon, R. and Mandhachitara, R. (2008) 'Causal path modeling of grocery shopping in hypermarkets', Journal of Product \& Brand Management, 17, 327-340

Soufun (2009) 104 Cities [Online] Available: http://www.soufun.com/SoufunFamily.htm [Accessed 10 August 2009]

Souiden, N. and Pons, F. (2009) 'Product recall crisis management: the impact on manufacturer's image, consumer loyalty and purchase intention', Journal of Product \& Brand Management, 18, 106-114

Tovar, P. (2009) 'The effects of loss aversion on trade policy: Theory and evidence', Journal of International Economics, 78, 154-167

Wang, C. X., Webster, S. and Suresh, N. C. (2009) 'Would a risk-averse newsvendor order less at a higher selling price?', European Journal of Operational Research, 196, 544-553

Wang, Y. P. and Murie, A. (1996) 'The process of commercialisation of urban housing in China', Urban Studies, 33, 971-989

Wooldridge, J. M. (2003) Introductory Econometrics: A Modern Approach, Australia, Southwestern College Publications

Wu, W. (1999) 'Reforming China's institutional environment for urban infrastructure provision', Urban Studies, 36, 2263-2282

Xiao, T. and Yang, D. (2008) 'Price and service competition of supply chains with risk-averse retailers under demand uncertainty', International Journal of Production Economics, 114, 187-200

Zilg, A. (2011) 'THAT'S AMORE: Brand names in the Italian food market', International Journal of Applied Linguistics, 21, 1-25

Zou, P. X. W., Zhang, G. and Wang, J. (2007) 'Understanding the key risks in construction projects in China', International Journal of Project Management, 25, 601-614 